\title{
A nação à deriva: a representação de Portugal em A jangada de pedra, de José
}

\section{Saramago.}

Melina Alves Melo Costa ${ }^{1}$

"Fita, com olhar esfíngico e fatal,
O Ocidente, futuro do passado.
O rosto com que fita é Portugal."

(Fernando Pessoa)

\section{Introdução}

A literatura encerra, em seu âmago, a possibilidade de ampliar a percepção e compreensão, pelo ser humano, das mais profundas questões inerentes à vida social e moderna em que ele se encontra. Isso se torna possível a partir do momento em que tais questões são problematizadas e desentranhadas por meio da transfiguração realizada pelo trabalho artístico, seja ele literário ou não. Desse modo, a estreita relação entre ficção, nação e História - não os fatos em si, mas aquela contada e produzida pelos historiadores também faz parte da gama dos nós mais apertados da sociedade, cujo desenlace verdadeiro e genuíno, porém nem sempre fácil - é encontrado pela via da arte.

Este ponto concerne ao fazer artístico produzido no mundo modernizado e capitalista no qual estamos inseridos, contexto responsável pela principal contradição da literatura: ao mesmo tempo em que há a impossibilidade de separação entre a arte e a realidade que a originou, a primeira não pode ser considerada alheia à segunda, como se fosse uma fonte de independência e redenção. Portanto, o fazer literário só torna-se capaz de lutar contra a coisificação do mundo quando conscientiza-se da sua própria condição e assume-se como reificada; a partir disso, ela torna-se apta a dar a ver os dilemas intrínsecos à realidade - tensões muitas vezes negadas aos nossos olhos, atrelando-nos a uma falsa liberdade. Devido à divisão de trabalho da sociedade moderna, a arte obteve um caráter autônomo, encerrando-se em si mesma, como se não devesse mais que falar de si. Nesse viés, ela acaba reduzida a uma mercadoria, funcionando apenas como mais um empecilho na nossa percepção do real. É necessária a compreensão do trabalho artístico como algo

\footnotetext{
${ }^{1}$ Matrícula: 08/37164
} 
repleto de carga histórica, no qual encontram-se inseridas todas as questões e contradições provenientes da sociedade capitalista e reificada em que vivemos.

A literatura mostra-se, assim, como um caminho eficaz para preencher as lacunas e brechas deixadas pela História - tarefa atingida justamente por meio daquilo que falta, do que a separa e distancia do real, como se "coubesse à ficção escrever uma História ainda (e talvez sempre) por conhecer nos seus pormenores e motivações mais recônditos, humanos e às vezes sórdidos" (REIS, 2005:295). A relações entre literatura e nação efetivam-se, muitas das vezes, com uma espécie de fuga que, ao contrário do que inicialmente espera-se, traz à tona diversos dilemas que, pelo viés da "realidade" pura e simples, sem intermédio da arte, permaneceriam ocultos. Como discorre Octavio Ianni em "Nação e narração":

a literatura é até mesmo uma forma sofisticada de conhecimento, no sentido de compreensão e esclarecimento, ainda que difusa e inconsciente. Surpreende o momento, a situação, o impasse, a tensão e a realização ou frustração. Pode revelar o real e o virtual, antes que os contemporâneos se dêem conta do que vai pelo mundo; prefigurando ações e sentimentos, subjetividades e entendimentos, probabilidades do ser e do devir (1999:79).

No entanto, a literatura adquire um novo contorno quando localizados em sociedades de caráter excepcional, como é o caso das nações periféricas. Assim, a literatura de Portugal e do Brasil, por exemplo, exibe toda uma maneira própria de formação e desenvolvimento, com características que só a condição marginal que possuem poderia permitir.

Portugal, em especial, apresenta uma realidade muito peculiar, repleta de contradições e ambiguidades, e cujo momento atual decorreu de um longo e complexo processo. Portanto, para compreender a literatura lá produzida e, mais especificamente, aquela posterior ao 25 de abril de 1974, na qual se inclui o romance $A$ jangada de pedra, de José Saramago (2006) - objeto de pesquisa do presente trabalho - torna-se imprescindível percorrer brevemente o fraturado percurso que Portugal perfez até se tornar o que é hoje.

\section{Breve panorama histórico de Portugal}

Logo à primeira vista, ressalta-se o fato da nação portuguesa, mesmo com todo o seu passado glorioso e sua localização no continente europeu - centro do mundo por excelência -, encontrar-se tão à margem da Europa quanto países da América do Sul e da África, suas antigas colônias. Segundo Eduardo Lourenço (1999:91), a própria transição de 
Portugal de reino a Estado caracteriza-se como uma exceção - a que o autor chama de "insólito milagre" -, pois o pequeno reino lusitano nada tinha de diferente de outros, como os de Catalunha, Aragão, Castela e Leão, que se unificaram para constituir uma só Espanha. No entanto, Portugal sobreviveu e consolidou-se de forma autônoma e independente como poucas outras nações o fizeram. Alguns séculos depois, passou pelo período áureo de sua existência, que até hoje ecoa sem cessar e cujo espectro paira sobre todos os lusitanos: o pioneirismo nas navegações ultramarinas e o descobrimento de várias e longínquas terras. É neste momento de apogeu do novo tempo imperial que ocorre um processo de dilaceramento do "velho tempo português", metamorfoseando a imagem de Portugal na de uma "grande nação", de modo que "encerramo-nos magicamente na esfera do Império e de lá olhamos e medimos com os olhos de sonho que o império não menos de sonho nos dera, essa Europa a que real e simbolicamente, primeiro do que ninguém, voltáramos as costas" (LOURENÇO, 1999:96). Tal passado glorioso - que encontra n'Os Lusíadas sua representação máxima - é o que ainda alimenta a identidade firme e bem definida que Portugal tem de si, já que é o seu único e derradeiro elo com a Europa em oposição à realidade apagada, secundária e periférica que possui atualmente.

Desse modo, torna-se compreensível a peculiaridade da relação de Portugal com a Europa, decorrente do alheamento daquele povo dos que se encontram além-Pirineus, isolamento este que se iniciou nas primeiras décadas do século XIX, segundo Eduardo Lourenço (1999). Para este autor, antes disso, mesmo o Portugal medieval possuía uma posição muito mais europeia do que a "ilha histórica mítica por excelência" que este país se tornou após a era das revoluções.

Depois da Independência do Brasil, seu principal domínio do século XVI ao XIX, Portugal encontrou na colonização da África, em partilha com as outras potências, uma possível restauração da imagem de "descobridor" que havia perdido. Nessa nova configuração, Portugal assume um papel ambíguo, como afirma Margarida Calafate Ribeiro (2004:26):

Nesta hierarquização de nações imperiais que entre si administravam o mundo na Age of Empire, Portugal jogava um ambíguo papel para si e para os outros: por um lado, o da nação pioneira na abertura europeia ao mundo, senhora dos primeiros passos da cultura universalista, que Camões assume patriótica e universalmente em Os Lusíadas e cujos desenvolvimentos constituem patrimônio do Ocidente, definindo Portugal como nação colonizadora e conferindo-lhe legitimidade histórica para reivindicar os 
seus territórios africanos consagrados constitucionalmente desde 1822; por outro lado, o da realidade contemporânea à corrida europeia para a África, o de uma nação imperial decadente e esvaziada, vítima da sua dependência do Brasil entretanto perdido, e de um país distante da Europa, dessa Europa simultaneamente científica, moderna, imperialista e "devoradora" em franco desenvolvimento económico, político e social [...] Como diria Boaventura de Sousa Santos, Portugal assumia assim e mais uma vez a sua condição intermédia que o colocava num espaço de fronteira, ou seja, entre a sua herança histórica espalhada pelo mundo e a periferia europeia que há muito era.

Mesmo com a dolorosa descolonização da África no século XX e, assim, a perda da única coisa concreta que ligava o presente decadente de Portugal ao seu passado grandioso, a identidade lusitana não sofreu grandes traumas e manteve-se estável como sempre fora. Apesar das guerras de Angola, Moçambique e outros países em processo de independência, que muito influenciou na atual configuração social lusitana, principalmente pelo fenômeno dos "retornados" - portugueses que estavam nas ex-colônias e voltaram para a metrópole -, Portugal viveu "a sua mais que modesta existência e mesmo a sua factual mutilação, sem traumatismo histórico e cultural notórios" (LOURENÇO, 1994:11). Eduardo Lourenço tributa essa indiferença de Portugal às colônias perdidas como uma confirmação do seu "enraizamento profundo no passado", mais uma evidência de que, nas palavras do autor, "só em termos de imaginário, e imaginário fabricado por uma ideologia arcaizante e reaccionária, a identidade nacional estava vinculada à existência de territórios ultramarinos" (1994:13). Tal "existência imaginária" é o que explica o fato de que

Nenhum desmentido brutal do presente, nenhuma consciência de nossa pouca influência ou importância política, económica e mesmo cultural no mundo contemporâneo, nem mesmo a recente experiência da amputação do seu espaço imperial, conseguiram alterar esse dado fundamental da autoconsciência nacional, essa espécie de bilhete de identidade íntimo que cada um de nós traz no bolso interior de sua alma: descobrimos e baptizámos a Terra, de Cabo Verde à Índia, do estreito de Magalhães às Filipinas (LOURENÇO, 1994:11).

Assim, a já ultrapassada ideia de Portugal como Império ultramarino funciona como uma "euforia mítica", que se justifica pelo papel messiânico exercido por essa nação em um momento em que a História ocidental figurava como História mundial. E, por mais que tenha sido esquecido ou ignorado pelos outros países, tal passado se sustenta como alicerce da "hiperidentidade" lusitana, bastando para tanto apenas o conhecimento dos próprios portugueses sobre sua história: "que os outros ignorem, saibam pouco ou o tenham 
esquecido, deprime-nos, mas não altera o essencial: nós sabemos, e esse saber é afinal a nossa única e autêntica identidade" (LOURENÇO, 1994:11).

Boaventura de Sousa Santos discorre sobre essa situação pós-moderna de Portugal na obra Pela mão de Alice (2008), ao afirmar que

Apesar de ser um país europeu e de os portugueses serem tidos por um povo afável, aberto e sociável, é Portugal considerado um país relativamente desconhecido. Apesar de ser um país com longa história de fronteiras abertas e de "internacionalismo" - das descobertas dos séculos XV e XVI à emigração dos anos sessenta -, é considerado um país exótico, idiossincrático. Desconhecimento e exotismo são, pois, temas recorrentes quando se trata de propor uma apreciação global do país e do seu povo. [...] Por outras palavras, sabe-se pouco sobre Portugal e, por isso, se considera ser Portugal um país relativamente exótico. [...] O desconhecimento de Portugal é, antes de mais, um auto-desconhecimento. O Encoberto é a imagem da ignorância de nós mesmos reflectida num espelho complacente. [...] Na ausência de adequada inovação teórica, corre-se o risco de analisar a sociedade portuguesa pela negativa, por aquilo que ela não tem quando comparada quer com as sociedades centrais, quer com as sociedades periféricas. Tal negatividade é uma outra forma de desconhecimento e por isso também campo fértil de análises míticas e de estipulações de exotismo, que são, neste caso, efeitos da inadequação dos instrumentos analíticos (2008:53, 54 e 58).

É inegável que a África possui papel fundamental na história lusitana, ainda mais considerando-a como o fomento de um dos eventos mais significativos no processo de configuração do Portugal dos dias de hoje: a Revolução dos Cravos. O que culminou em 25 de abril de 1974 teve origem na África, pois dependeu da difusão de um mesmo aparato ideológico que circulara tanto na metrópole quanto nas colônias. Resumindo nas palavras de Lincoln Secco: "Da perda da América, passaram os portugueses a buscar a miragem de 'novos Brasis' no continente negro. E na iminência da perda da África, voltaram-se para o que, de fato, sempre buscaram: a Europa” (2004:20). Assim, “A crise do Império português é metropolitana. E é colonial. Por isso não se pode olvidar o ultramar" (SECCO, 2004:58). Esse novo acontecimento, que pôs fim à ditadura salazarista iniciada em 1933 - em conjunto com as transformações de fim de século - refletiu-se em uma nova maneira de representação literária portuguesa, cujo desenvolvimento obteve maior relevância e eficácia estética no gênero do romance, tema que será tratado a seguir. 
3. O romance pós-25 de abril de 1974

No último quarto do século XX, devido às mudanças sofridas por Portugal no plano social e político e as novas vivências permitidas com o fim de um regime ditatorial e opressor - o retorno da liberdade de expressão -, a ficção portuguesa abre-se a significados discursivos próprios do pós-modernismo. Tais valores consistem na revisão dos conflitos oriundos da guerra colonial e no novo delineamento das fronteiras, causado pela perda dos territórios africanos, assim como na conscientização e problematização das questões identitárias, tão arraigadas na trajetória histórica lusitana e que se intrincaram ainda mais com esse novo momento pós-colonial.

A literatura, após ter passado por um pequeno período "estéril" e pouco produtivo de cerca de dois anos, em uma espécie de reajuste e acomodação à nova realidade portuguesa depois de 41 anos de ditadura, retornou o ímpeto criativo com muita força no plano metaficcional. Assim, os autores voltaram seus interesses para discussões sobre a pluralidade de olhares de um mesmo objeto, bem como o papel da memória no processo de representação da realidade. Além disso, a História, no seu tempo presente, passa a ser foco dessa nova fase da literatura, assim como os vários problemas políticos e sociais desse momento e o testemunho da geração que os vivenciou. No entanto, o que toma maior vulto são os questionamentos metaliterários, que se refletem esteticamente em uma tendência ao inacabamento, a uma escrita assumidamente precária e à intensa subjetivização do narrador ou das muitas vozes narrativas. Como afirma Carlos Reis (2005:293), há um "processo nunca concluído de incessante busca, em que o sujeito surge como identidade estilhaçada, mas não imune a incursões líricas e ensaísticas".

Pode-se destacar como outras inovações realizadas na literatura pós-moderna portuguesa a recuperação de gêneros do passado - como a epopeia e o romance histórico, por exemplo; uma assumida intertextualidade, em um discurso que dialoga com textos tanto literários como não-literários e que possibilita também a paródia; enunciados, como já dito, metaficcionais e metadiscursivos, que indagam a legitimidade da narrativa canônica e fundadora de identidade; e a nova representação da História pelo viés ficcional e alegórico - que, no caso português, implica a valorização da guerra colonial como tema e as indagações da configuração pós-colonial. 
Assim, com o foco da literatura voltado para as lesões ideológicas acarretadas pela guerra colonial, a ficção portuguesa pós-25 de abril de 1974 mostra-se indissociável das vivências e experiências históricas, em uma constante projeção destas naquela. Como afirma Carlos Reis (2005:302),

[...] a literatura da guerra colonial constitui, em geral, uma espécie de antiepopeia ou, no mínimo, de revisão do sentido de epopeia, tal como o salazarismo a impôs, particularmente na leitura 'oficial' e imperialista a que sujeitou Os Lusíadas, como obra central do cânone; [...] De um modo geral, essa literatura procede à representação ficcional de uma dramática experiência de vida (o que não inibiu alguns escritores de a cultivarem, sem terem estado em África), equacionada como literatura de guerra, na decorrência histórica da colonização e da sua falência, nos anos 60 e 70.

José Saramago - ao lado de outros autores, como António Lobo Antunes -, tomou a problematização da História como o centro de sua obra ficcional, refletindo sobre "questões cruciais do homem, da sociedade e da literatura do seu tempo" (REIS, 2005:307). Percebese, em alguns dos seus romances, o que Carlos Reis (2005) denomina "dupla emergência": a primeira consiste na frequente retomada de lugares, figuras e eventos históricos, transplantados com naturalidade à ficção; a segunda surgiria da necessidade de meditar sobre eles a partir da ótica presente e de uma matriz cultural marxista. E essa nova interpretação de símbolos e personagens históricos ganha força com a utilização, no discurso literário, da ironia, da paródia e do sarcasmo. No entanto, após ter recebido o prêmio Nobel da literatura e, por conseguinte, ter ganhado projeção internacional de seu trabalho, Saramago deixou de lado os temas relacionados ao imaginário português em sua obra mais recente para se dedicar a questões sobre a ética e a condição humana.

É de grande importância destacar, além do que já foi dito, a grande ampliação de uma literatura de temática e configuração discursiva femininas na ficção portuguesa pósmoderna, em que esse gênero constitui-se como eixo de referência estética, social, mental e ideológica. Dentre os principais nomes, pode-se apontar Lídia Jorge, Teolinda Gersão e Maria Gabriela Llansol, em que a pulsão do feminino manifesta-se por meio da linguagem, fundindo tradição, memória e culto das origens. Como bem resume José Rodrigues de Paiva,

Desta literatura, na qual, como referência cronológica e temática a Revolução de Abril se levanta como fronteira a separar o imediatamente antes do imediatamente depois, dois aspectos (entre tantos outros pesquisáveis) fazem-se notar por sua expressividade. Um deles situado 
apenas quanto a questões de gênero no universo autoral, mas com inegáveis desdobramentos de interesse no universo e caracterização da criação literária: o de uma intensa e crescente presença e participação feminina no processo de renovação da escrita portuguesa. $\mathrm{O}$ outro ligado a questões estruturais dessa renovação: o da auto-reflexividade na narrativa ficcional. [...] Como se o pretendido espírito renovador da revolução política se estendesse aos domínios da literatura, esta ingressou, também - e particularmente no romance, num tempo de renovação de linguagens, estruturas e propósitos em que é predominante o traço da autoreflexividade da narrativa, reforçando a tendência de um romance ao qual passava a interessar menos a representação realística e mais a problematização do próprio gênero romance [...] (2010:27 e 28).

\section{Literatura e nação}

Para que se pense o diálogo entre nação e literatura, é capital refletir inicialmente sobre como se constituiu o conceito de nação difundido atualmente. No senso comum, ela é considerada como algo que sempre existiu, um pressuposto. No entanto, ela nada mais é do que um artefato, um constructo que não pode ser pensado como algo perene, natural, definitivo. A ideia de nação, na verdade, foi criada e edificada no século XIX e encontra-se de mãos dadas com a modernidade, caracterizando-se como um conceito moderno por excelência. Assim, a sua definição não pode se reduzir a língua, território, cultura, folclore, etc - tais fatores não são suficientes, não dão conta dessa concepção de nação; além disso, ela está relacionada a um sistema de governo forte, de economia consistente, com relações sociais complexas e que tem como pano de fundo a era das revoluções e o liberalismo (HOBSBAWM, 1990).

Paulo Arantes, em "Nação e reflexão" (2006), problematiza tal questão a partir das ideias de nacionalismo de Ernest Gellner e Benedict Anderson. Ambos sustentam a concepção de nação como invenção, artefato e imaginação, que provêm da necessidade moderna de homogeneidade em uma sociedade marcada pela desigualdade e pelo antagonismo. Pode-se dizer que a nação se configura como uma comunidade imaginada porque, apesar de seus membros jamais chegarem a ter contato com a totalidade de seus compatriotas - por menor que ela seja -, haverá sempre em cada um deles um inquestionável sentimento de aliança e comunhão.

A partir disso, a nação pode ser concebida também como uma narrativa, assim como apontou Octavio Ianni (1999:71). E, dentre essas possíveis formas de narração, destaca-se a literatura. Então, voltamos o nosso olhar, novamente, para aquilo que Antonio Candido 
procurou exercer - e no que teve êxito - na sua trajetória como crítico literário: o estudo analítico da interiorização, no objeto literário, dos dilemas, impasses e tensões mais profundamente entranhadas na sociedade ou no modo brasileiro de formação da nacionalidade. Assim, o externo vira interno, o social transfigura-se em estético, de modo que o texto torna-se capaz de revelar o contexto (CANDIDO, 2006:13). Por isso, considerar o que se encontra expresso na superfície da obra literária como um reflexo direto da realidade, uma representação idêntica daquilo que se observa, é cair no erro de não enxergar justamente o que mais interessa e mais tem a dizer: a implícita presença do real na estrutura artística. Como afirma Ianni, "Sob vários aspectos, pois, a tessitura do texto esconde ou revela a tessitura do contexto" (1999:74). E complementa:

Esta é uma questão essencial: a literatura tem sido uma espécie de sismógrafo das configurações socioculturais, em suas vivências, formas de sociabilidade, subjetividade e ilusões. Pode-se falar em localismo e cosmopolitismo, regionalismo e nacionalismo, exotismo e ecletismo, romantismo e modernismo. Em todos os casos, os escritos ressoam algo ou muito do que têm sido as conformidades e as tensões, as inquietudes e as fabulações de uns e de outros, tanto indivíduos como coletividades. É como se a literatura fosse uma forma privilegiada de autoconhecimento, ao mesmo tempo que de deslumbramento. (1999:79)

Desse modo, tratando-se da representação da nação na literatura, há que se considerar o caráter fantasioso, deformador e imaginativo que esta ocasiona naquela. Ingênuo quem crê que, para fazer literatura sobre um acontecimento histórico ou de grande importância no curso de uma nação, é preciso ater-se a datas, documentos oficiais, cartas, depoimentos, gravações, etc. Esse registro, sem dúvida, é de grande valia, porém não consegue dar a ver os pontos mais essenciais de uma realidade social - até porque, caso isso fosse suficiente para tanto, que função teria a arte? Logo, o fantástico, o fantasmagórico, o alegórico e o fabuloso são exemplos de recursos estéticos capazes, por meio da extrapolação, de revelar muita verdade sobre aquilo que distorcem. Ou como discorre Teresa Cristina Cerdeira (2000: 198 e 201):

A questão desemboca numa reflexão sobre a linguagem, na sua dinâmica relação com o referente - neste caso, a História -, no seu poder de dizer sempre diferentemente o real, porque o apreende sob a forma discursiva, na sua falência em repeti-lo idêntico num plano outro que é o plano da linguagem. [...] Já a ficção ultrapassa a falência por uma exarcebação da falência, daquela impossibilidade de a linguagem dizer de forma idêntica o referente. Tece-se, justamente, deste logro e desta criação, faz explodir as fronteiras do imaginário e afasta-se - consciente e voluntariamente - do 
objecto, para se construir como imagem dele. Como imagem, a linguagem é a própria ausência do facto, é mais que a consciência ou a denúncia de uma impossibilidade, mas o terreno mais-que-fértil de uma contrapartida da ficção, aquela "trapaça", aquela "esquiva", aquele "logro magnífico" a que Barthes chamava "literatura".

O próprio José Saramago, que dedicou boa parte de sua produção literária ao romance histórico, também discorre sobre esse tema e a possível conciliação entre literatura e História:

Diria eu que a História, tal como se escreve, ou - repetindo a provocação tal como a fez o historiador, é primeiro livro, não mais que o primeiro livro. [...] Restará sempre, contudo, uma grande zona de obscuridade, e é aí, segundo entendo, que o romancista tem o seu campo de trabalho. Creio bem que o que subjaz a esta inquietação é a consciência da nossa incapacidade final para reconstituir o passado. [...] Duas serão as atitudes possíveis do romancista que escolheu, para a sua ficção, os caminhos da História: uma discreta e respeitosa, consistirá em reproduzir ponto por ponto os factos conhecidos, sendo a ficção mera servidora duma fidelidade que se quer inatacável; a outra, ousada, levá-lo-á a entretecer dados históricos não mais que suficientes num tecido ficcional que se manterá predominante. Porém, estes dois vastos mundos, o mundos das verdades históricas e o mundo das verdades ficcionais, à primeira vista inconciliáveis, podem vir a ser harmonizados na instância narradora (REIS, 2005:322).

A literatura em Portugal apresenta-se de maneira bastante peculiar, devido a sua condição de país periférico, como já foi dito, por possuir uma posição secundária e dependente dos moldes culturais do centro. Apesar de se aproximar nesse aspecto do material literário produzido nas nações da América Latina, a literatura lusitana em muito se difere deste. Isso decorre do fato de Portugal já ter tido o seu "momento de glória", tanto na esfera social e econômica - grande potência dominadora de territórios em vários pontos do globo -, como no âmbito literário - a obra camoniana e principalmente Os Lusíadas foram e continuam sendo fonte inesgotável de inspiração e revisitação. Enquanto Portugal tem, na história e na tradição do passado, um contraponto à decadência que vem experienciando, os países latino-americanos, em contrapartida, não possuíam uma tradição literária precedente e tiveram de criar, ao mesmo tempo, pátria e literatura.

Portanto, pode-se ampliar ao campo da literatura uma característica que Boaventura de Sousa Santos atribuiu à nação portuguesa: o estatuto de semiperiférica, que se assinala "tanto pela construção de imagens de centro, naturalmente imperiais, arquétipos da 
grandeza pátria, como de imagens de periferia, ligadas a uma decadência secular e a uma vivência quotidiana nem sempre farta em riqueza e imaginação" (RIBEIRO, 2004:28).

Voltemos agora nossos olhares para a obra que serviu como mote para essa pesquisa - A jangada de pedra, de José Saramago -, a fim de verificar no objeto literário as tensões tanto literárias e estéticas quanto sociais e identitárias, previamente apresentadas nesse trabalho.

\section{Análise do romance $A$ jangada de pedra}

A jangada de pedra, sexto romance de José Saramago, foi publicado em 1986, momento em que o autor escreve uma série de romances históricos, como, por exemplo, Levantado do chão (1980), Memorial do convento (1982) e $O$ ano da morte de Ricardo Reis (1984). Nesse mesmo ano de 1986, efetivou-se a entrada de Portugal e Espanha na Comunidade Econômica Europeia (CEE), atual União Europeia. Além disso, ainda havia a condição pós-25 de abril de 1974 e o consequente advento dos "retornados", configuração que se opunha à crescente modernização do país. Célia Branco situa de forma breve o contexto de publicação da obra:

Quando A Jangada de Pedra foi publicada, dois momentos marcantes da História lusa pairavam na contemporaneidade portuguesa. Acordava-se de um sonho utópico e vivia-se uma realidade que em nada traduzia essas aspirações de igualdade, justiça, fraternidade e liberdade. A Revolução dos Cravos, em Abril de 1974 significou o final da ditadura de Salazar e do colonialismo, bem como a abertura de Portugal ao resto do mundo; no entanto, também provou que muito da ideologia revolucionária nunca se viria a concretizar, ficando o país dividido em diferentes horizontes políticos, situação ademais agravada pelo regresso de centenas de milhares de portugueses das ex-colónias e pelo desaparecimento do bloco soviético (símbolo máximo da utopia comunista). $\mathrm{O}$ desejo de uma sociedade igualitária nunca foi atingido. Da mesma forma, a entrada na União Europeia significou para Portugal uma evidência acrescida da sua condição de país periférico e das suas dificuldades em acompanhar o desenvolvimento europeu e mundial. (2008:3)

Tais circunstâncias são transplantadas para a obra literária - como já indica a epígrafe de Alejo Carpentier - pela via do fabuloso: surge uma rachadura na cordilheira dos Pirineus, na fronteira com a França, que cresce até que ocorra a total separação entre a Península Ibérica e o restante da Europa. Tal fato é incontornável e incapaz de ser explicado pelas vias da ciência: "Não podia a força humana nada a favor duma cordilheira 
que se abria como uma romã, sem dor aparente, e apenas, quem somos nós para o saber, porque amadurecera e chegara o seu tempo" (SARAMAGO, 2006:28).

Unidos a esse extraordinário acontecimento - e, de algum modo, responsáveis por ele -, estão cinco personagens: Joana Carda, Joaquim Sassa, Pedro Orce, José Anaiço e Maria Guavaira, juntos com o cão Ardent. Todas essas figuras têm em comum um caso insólito, que faz com que eles se sintam ligados à separação da Península: Joana Carda risca o chão com uma vara de negrilho - risco que de maneira alguma se apaga - e, no mesmo momento, todos os cachorros da cidade de Cerbère, que outrora eram mudos, desatam a latir; Joaquim Sassa, andando pela praia, lança uma pedra muito pesada ao mar com incrível força, fazendo com que ela ricocheteasse na água diversas vezes; Pedro Orce põe os pés no chão e passa a sentir uma vibração da terra, como um contínuo terremoto, sem que nenhuma outra pessoa sinta também tal tremor; José Anaiço começa a ser seguido de repente por um bando de estorninhos; e Maria Guavaira desfaz um pé de meia que nunca tem fim, apesar de já ter a sua casa inundada em um monte de lã azul. O cão, por sua vez, estava na fronteira quando surgiu a primeira rachadura dos Pirineus e, no momento da divisão, optou "pelas regiões infernais", e saltou do lado francês para as terras da Península. Em meio a esses extraordinários acontecimentos, o romance gira em torno do mote da viagem: seja a viagem que a própria península executa - "viagem como nunca se viu outra" (2006:106) -, seja a que os personagens desenvolvem no seu interior, percorrendo várias regiões de Portugal e da Espanha, em uma viagem dentro da viagem. Um dos próprios personagens reflete sobre isso, quando afirma que “[...] nós aqui vamos andando sobre a península, a península navega sobre o mar, o mar roda com a terra a que pertence, e a terra vai rodando sobre si mesma, e, enquanto roda sobre si mesma, roda também à volta do sol [...]" (2006:234 e 235).

Além disso, ocorre uma viagem existencial, em que os personagens buscam o autoconhecimento, a descoberta de si próprios e do amor. O que impulsiona cada uma dessas cinco figuras a se deslocarem pela península, buscando uns aos outros, é o desejo de compreender si mesmo, a partir do encontro com seus iguais - outras pessoas que também protagonizaram algum acontecimento inexplicável. Inicia-se, assim, com o aprofundamento das relações entre eles, a descoberta e a vivência de sentimentos vários, que desembocam na tomada de consciência do próprio ser. Verificamos isso na seguinte fala da personagem 
Joana Carda: "Se fui a Lisboa procurá-los, não terá sido tanto por causa dos insólitos a que estão ligados, mas porque os vi como pessoas separadas da lógica aparente do mundo, e assim precisamente me sinto eu" (SARAMAGO, 2006:127). Portanto,

a viagem é uma viagem da terra que, através dos mares, busca outra terra, uma viagem dos homens que, sobre a terra (numa carroça que tem também o nome comum de galera), se buscam para se unirem na amizade e no amor, partindo de uma interrogação inicial, prosseguindo em corrente humana reforçada, trocando e partilhando os diversos viáticos, e buscando um sentido que encontram afinal na sagração de si mesmos como entidades definidas e conscientes de um fim, de um recomeço e, sobretudo, de uma mobilidade interior (SEIXO, 1998:34; apud BRANCO, 2008:12).

Ao tomar conhecimento, pela mídia, do homem que sentia a terra tremer, o funcionário de escritório Joaquim Sassa vai de encontro ao farmacêutico espanhol Pedro Orce, com o qual descobre um outro homem responsável por um fato extraordinário, levando-os até o professor José Anaiço. Joana Carda, por sua vez, toma conhecimento desses três homens - que chegam a ser procurados pela polícia e cujos casos são noticiados na televisão - e vai ter com eles em Lisboa, no Hotel Bragança, onde estão hospedados mesmo hotel em que se alojou Ricardo Reis quando da morte de Fernando Pessoa, em romance anterior de Saramago, O ano da morte de Ricardo Reis (1984). Ao se encontrar do Joana Carda e sua vara de negrilho, José Anaiço é abandonado pelos milhares de estorninhos que o seguiam até então. Inicia-se entre ele e Joana Carda - cujo casamento havia acabado recentemente - um romance imediato, como o resultado de uma identificação e um reconhecimento mútuos. Forma-se, assim, o primeiro casal do grupo de viajantes.

Essas personagens vagueiam por diversos caminhos da Península, até se encontrarem com o cão Ardent, que adquire o posto de guia dos quatro. O cachorro os conduz à casa da viúva galega Maria Guavaira, que espera na porta portando na mão o mesmo fio de lã azul que Joaquim Sassa retirou da boca do cão Ardent e também segurava. Assim, como ocorreu com Joana Carda e José Anaiço, ambos começam um relacionamento amoroso logo no momento em que se conhecem. Pedro Orce, por sua vez, acaba por se isolar de seus parceiros, mantendo o cachorro como sua principal companhia, o que se deve tanto à diferença linguística - ele era o único que falava espanhol - quanto pela nova 
configuração do grupo - que, de cinco pessoas e um cão, passou a ser formada por dois casais, um espanhol um cão.

Quando partem na galera a fim de chegar ao local de separação da península, as duas mulheres percebem a solidão de Pedro Orce e decidem, sem terem feito algum tipo de planejamento, ter relações sexuais com ele, o que quebra a harmonia do grupo. Além disso, ambas engravidam - assim como todas as outras mulheres férteis da península -, porém sem saberem quem é o pai do filho que esperam. Após terem se deparado com o abismo na cordilheira, no caminho de volta, Pedro Orce pisa ao chão, sente que a terra parou de tremer e morre. Os outros, então, o levam até Venta Micena para enterrarem seu corpo e sobre sua sepultura fincam a vara de negrilho.

Percebemos que os personagens, antes pessoas comuns, tornam-se singulares após os acontecimentos insólitos que os ligam. Abandonam a trivialidade de suas vidas para seguir em uma viagem que, acima de tudo, é uma busca individual por si próprio. Para tanto, além de viverem uma reviravolta no seu cotidiano com as adversidades da separação da Península, os cinco personagens experimentam o amor, a amizade, a solidão, a compaixão, o ciúme. E, juntos, seguirão "o seu caminho, que futuro, que tempo, que destino", agarrados à esperança que o possível florescimento da vara de negrilho propõe da qual falaremos mais adiante.

Ainda no que concerne às personagens, é interessante abordar a presença da figura feminina na obra, muito marcante e repleta de simbologias. Teresa Cristina Cerdeira discorre sobre isso, quando afirma que

Em A jangada de pedra, a questão do feminino não se põe só através das duas mulheres detentoras cada uma de um objeto mágico - a vara de negrilho de Joana Carda e o fio azul de Maria Guavaira. Aqui é também feminina a terra-jangada, mulher que já não fica mas parte pelo mar, que se dispõe a conhecer, a aprender, a viajar, recusando o terceiro postulado da subalternidade cultural: "o melhor livro é a almofada e o bastidor". Essa península que já é ilha, e, mais que ilha, é jangada que lhe confere movimento, sedução e liberdade, acorda para a sua autognose, para o destino encarado de frente, ao lado de culturas irmãs, entre a América Latina e a África. Se, por um lado, em se fazendo ilha, escapa por vontade própria ao espaço da marginalidade peninsular que lhe impusera a Europa, ao simbolicamente incluí-la como periférica por mantê-la geograficamente ligada por um breve istmo que são os Pirenéus, por outro, essa jangada que navega rumo ao Atlântico Sul sabe-se livre porque se quer longe também dos desvarios imperialistas do passado (2000:220). 
Ao nos focarmos em outro ponto da obra, vemos que o romance $A$ jangada pedra também caracteriza-se como uma alegoria do período por que Portugal estava passando, sem deixar de dialogar com o glorioso passado das navegações - grande suporte identitário dessa nação em decadência. É por meio de uma estética alegórica e fantástica que Saramago une esses dois extremos portugueses: de um lado, a separação da há muito longínqua Europa, representando a condição periférica de Portugal nesse continente; de outro, o retorno às navegações, como nau que mais uma vez se lança ao desbravamento de “mares nunca dantes navegados”. O momento da total separação da Península é descrito no trecho seguinte:

Então, a Península Ibérica moveu-se um pouco mais, um metro, dois metros, a experimentar as forças. [...] Houve depois uma pausa, sentiu-se passar nos ares um grande sopro, como a primeira respiração profunda de quem acorda, e a massa de pedra e terra, coberta de cidades, aldeias, rios, bosques, fábricas, matos bravios, campos cultivados, com a sua gente e os seus animais, começou a mover-se, barca que se afasta do porto e aponta ao mar outra vez desconhecido. (2006:39)

Agora, Portugal e Espanha apresentam-se como uma "ilha" - denominação mais próxima do que seria esse bloco de terra que se desloca pelo oceano - característica que já pertencia a esses países de forma simbólica, principalmente a Portugal. Eduardo Lourenço afirma ser a situação lusitana singular, visto que durante séculos "viveu e se viveu simbolicamente como ilha, sendo ao mesmo tempo um povo que desde os séculos XV e XVI se instalara no papel de descobridor e colonizador, em terras de África, do Oriente e do Brasil" (1999:95), singularidade que Saramago capta e transfigura na metáfora da jangada.

As articulações entre passado e presente, centro e periferia e arcaico e moderno são extremamente desenvolvidas ao longo da obra, ligações muitas vezes efetivadas pela figura do narrador - cujo papel é de enorme importância no romance. Esse narrador faz, a todo o tempo, digressões, questionamentos e reflexões, seja sobre a condição da Península Ibérica e de seus habitantes, sobre a língua portuguesa e o fazer literário ou sobre o próprio ser humano e seus conflitos. Além disso, também estabelece intertextos, diálogos e frequentes referências à tradição popular e literária portuguesas. O narrador promove um trabalho incessante de citação, alteração e recriação de ditados populares, bem como de revisitação d'Os Lusíadas, obra da tradição portuguesa por excelência. Seus comentários entrelaçam a 
narrativa, partindo sempre de indagações a fim de promover novas interpretações daquilo que trata. Como explica Célia Branco,

O narrador, não só orienta o leitor nesta história fantástica, como também reflecte sobre o contexto político-social em que a narrativa se desenrola, reavivando e reescrevendo em simultâneo memórias histórico-culturais. O narrador de A Jangada de Pedra recorre a contextos mágicos, mitológicos e alegóricos e, em sucessivas digressões, no jogo metaficcional e autoreflexivo que estabelece com os leitores, incita à meditação sobre o significado das palavras e sobre a identidade humana (2008:2).

As referências literárias são inúmeras, e perpassam desde Luís de Camões, Fernando Pessoa, Mário de Sá-Carneiro e outras obras do próprio Saramago até as quadras populares portuguesas, transmitidas de geração em geração por meio da oralidade. Muito dessa intertextualidade apresenta-se sem nenhuma indicação, e o modo como aquele que lê irá reagir a isso depende do tipo de leitor que ele se configura. Diante de um leitor ingênuo, tais intertextos podem passar quase todos despercebidos - talvez um ou outro lhe remeta alguma familiaridade, quando se tratam das citações mais conhecidas; já no leitor atento, tais referências inquietam-no, fazendo com que ele busque a origem das informações além do romance e adquira uma certa desconfiança do narrador. Isso causa até um sentimento de frustração nesse segundo tipo de leitor, já que ele se depara com a impossibilidade de tomar conhecimento do vasto arcabouço e do saber enciclopédico de que o narrador se apropria e lhe apresenta a todo momento. Acerca dessa intertextualidade e sobretudo no que diz respeito a $O s$ Lusíadas, Teresa Cristina Cerdeira afirma que

Os Lusíadas são, assim, aquele pé-de-meia que, por mais que se desfaça, não chega nunca ao seu fim: Maria Guavaira "passou uma hora e outra e outra, e o longo fio de lã azul não pára de cair, porém o pé-de-meia parece não diminuir de tamanho". E não finda porque essa "desenredadeira" intui que o seu acto criador começa por um desfazer, por uma recusa da repetição, por uma península des-orientada, "desterritorializada", em busca de seu rumo, por uma ficção que reutiliza fios para perder-se de novo. Chamar a Os Lusíadas pé-de-meia inesgotável talvez pareça epíteto pouco sacralizador, mas dá conta de uma aventura na produção de sentidos que relança em bases voluntariamente heréticas a relação entre o Criador e as suas criaturas (2000, p. 269).

O retorno à mitologia - seja ela grega, romana ou concernente ao próprio Portugal também é frequente na obra, são muitas as referências. Tal ponto merece destaque, visto que segundo Eduardo Lourenço, em Portugal a "visão mitológica antecede a histórica" (1999:93), o que Boaventura de Sousa Santos explica quando declara que 
A partir do século XVII, Portugal entrou num longo período histórico dominado pela repressão ideológica, a estagnação científica e o obscurantismo cultural, um período que teve a sua primeira (e longa) manifestação na Inquisição e a última (assim esperamos) nos quase cinquenta anos de censura salazarista. A violação recorrente das liberdades fez com que acabasse por dominar a crítica da razão geradora dos mitos e esquecimentos com que os portugueses teceram os seus desencontros com a história (2008:54).

A metaficção, recurso literário marcante na narrativa portuguesa que sucedeu a Revolução dos Cravos, é outro traço forte d'A jangada de pedra. Na obra, são destrinchados os significados das palavras, as diferentes línguas e os problemas de tradução, estabelecendo o português como base para comparação. O próprio processo de escrita é diversas vezes analisado pelo narrador, como no excerto que se segue:

Dificílimo acto é o de escrever, responsabilidade das maiores, basta pensar no extenuante trabalho que será dispor por ordem temporal os acontecimentos, primeiro este, depois aquele, ou, se tal mais convém às necessidades do efeito, o sucesso de hoje posto antes do episódio de ontem, e outras não menos arriscadas acrobacias, o passado como se tivesse sido agora, o presente como um contínuo sem princípio nem fim, mas, por muito que se esforcem os autores, uma habilidade não podem cometer, pôr por escrito, no mesmo tempo, dois casos no mesmo tempo acontecidos (2006:11).

E também no trecho seguinte:

Não falta por aí, nunca faltou, quem afirme que os poetas, verdadeiramente, não são indispensáveis, e eu pergunto o que seria de todos nós se não viesse a poesia ajudar-nos a compreender quão pouca claridade têm as coisas a que chamamos claras. [...] De mais nos tem ensinado a experiência quanto são insuficientes as palavras à medida que nos aproximamos da fronteira do inefável, queremos dizer amor e não nos chega a língua, queremos dizer quero e dizemos não posso, queremos pronunciar a palavra final e percebemos que já tínhamos voltado ao princípio (2006:279 e 280).

Pode-se perceber na obra, seja na fala do narrador ou de outros personagens, uma consciência da condição periférica do Portugal e até um certo sentimento de inferioridade. Não são poucas as ocasiões em que ele é designado como "infeliz" e "pequeno país", tanto em comparação com a Espanha - na pequena escala da ilha em que agora navegam - como em relação à "Europa civilizada e culta". Isso se evidencia em falas como "não podemos ignorar que os problemas da nossa comunicação com a Europa, já historicamente tão complexos, irão tornar-se explosivos" (2006:38) - de um governante ibérico -, "aqueles 
portugueses todos que olhavam olhavam e não viam nada, não queiramos ser como eles" (2006:81) e "Portugal e Espanha terão de resolver os seus problemas locais, menos os espanhóis do que nós, que a eles sempre a história e o destino trataram com mais do que evidente parcialidade" (2006:185) - ambas do narrador.

Em diversos momentos há a constatação de que a separação do continente Europeu já havia se efetivado há muito tempo, e o que agora se estabelecia era apenas um rearranjo geográfico, conformando essa realidade ao mapa:

Os europeus, desde os máximos governantes aos cidadãos comuns, depressa se tinham acostumado, suspeita-se que com um inexpresso sentimento de alívio, à falta das terras extremas ocidentais, e se os novos mapas, rapidamente postos em circulação para a actualização cultural do popular, ainda causavam à vista um certo desconforto, seria tão-somente por motivos de ordem estética [...]. Com a continuação dos séculos, se eles continuarem, a Europa nem se lembrará mais do tempo em que foi grande e se metia pelo mar adentro [...] (2006:138).

Em uma das reuniões da CEE, logo após a separação da península, verificamos esse tom de desprezo e desdém pelos países ibéricos, recém admitidos no bloco econômico: "[...] alguns países membros chegaram a manifestar um certo desprendimento, palavra sobre todas exacta, indo ao ponto de insinuar que se a Península Ibérica se queria ir embora, então que fosse, o erro foi tê-la deixado entrar" (2006:38 e 39). Mais à frente na narrativa, ocorre uma insurgência dos jovens europeus em favor das nações da Ibéria, movimento cujo lema foi "Nós também somos ibéricos!", espalhada e difundida em todos os idiomas. Inicialmente essa agitação foi considerada passageira, mas devido às grandes proporções que adquiriu, as autoridades passaram a preocupar-se e logo buscaram, por meio de programas de televisão com pessoas que tinham deixado a península no primeiro sinal de sua separação, mostrar a esses "anarquistas" que a Europa era a melhor opção:

Essas pessoas traçaram o negro quadro das realidades ibéricas, deram conselhos, com muita caridade e conhecimento de causa, aos irriquietos que imprudentemente estavam a pôr em perigo a identidade europeia, e concluíram a sua intervenção no debate com uma frase definitiva, olhos nos olhos do espectador, em atitude de grande franqueza, Faça como eu, escolha a Europa. O efeito não foi particularmente produtivo, a não ser nos protestos contra a discriminação de que tinham sido vítimas os partidários da península, os quais, se a isenção e o pluralismo democrático não fossem palavras vãs, deveriam ter estado presentes na televisão para exporem as suas razões, se as tinham (2006:141). 
Porém, após certa movimentação nas ruas, frases pintadas por todos os cantos e em todas as línguas, embates com a polícia, alguns feridos e pouquíssimos mortos, os rebeldes acomodam-se, voltando ao sentimento de indiferença pelos países ibéricos de outrora manifestação passageira a que os psicólogos atribuíram não o desejo dos jovens de serem ibéricos, mas sim de se rebelarem, tendo sido esse um mero motivo decorrente do contexto em que se encontravam.

Em contrapartida a isso, vê-se que o povo, a grande massa, reage com indiferença às transformações decorrentes desse acontecimento e levam a vida como se nenhuma mudança tivesse ocorrido, em oposição à efervescência que ocorre na Europa:

Mas dentro das casas as luzes já estão acesas, ouvem-se vozes calmas, de gente cansada, um choro discreto no berço, em verdade os povos são inconscientes, lançam-nos numa jangada ao mar e continuam a tratar das vidas como se estivessem numa terra firme para todo o sempre [...] (2006:52).

E mais adiante:

Uma pessoa habitua-se a tudo, os povos ainda com mais facilidade e rapidez, afinal é como se agora viajássemos num imenso barco, tão grande que até seria possível viver nele o resto da vida sem lhe ver proa ou popa, barco não era a península quando ainda estava agarrada à Europa e já muita era a gente que de terras só conhecia aquela em que nascera, digam-me então, por favor, onde está a diferença (2006:120).

A partir disso, podemos adentrar em um ponto que chama bastante a atenção na obra: o poder exercido pela mídia sobre a população. Nas configurações dos olhares sobre Portugal ora apresentados, a televisão, o rádio e a mídia impressa são os principais responsáveis pelo direcionamento da opinião de seu público - característica da pósmodernidade já consolidada nos anos 80, quando Saramago escreveu o romance, e que se mostra cada vez mais presente e intensa. As únicas informações a que a grande massa tem acesso são adquiridas por meio do que é dito nos canais midiáticos, sempre assinalados pela pretensa busca de informações confiáveis e de cunho científico, quando na verdade são movidos por um tom de parcialidade e sensacionalismo. É por meio da mídia também que se tenta convencer os manifestantes europeus em favor dos ibéricos da inferioridade desses países, sem que a eles fosse concedida a possibilidade de exporem seus motivos, como mostra o excerto apresentado anteriormente. $\mathrm{O}$ autor dá um grande destaque ao que é dito e escrito na mídia, e um exemplo são as manchetes dos jornais, como pode-se verificar no 
seguinte trecho, quando da descoberta pela imprensa dos casos insólitos de Jaquim Sassa, Pedro Orce e José Anaiço:

José Anaiço deixou-se ficar na paz do hotel, esperando o regresso dos companheiros, pediu jornais, as entrevistas vinham todas na primeira página, com fotografias explosivas e títulos dramáticos, Enigmas Que Desafiam A Ciência, As Forças Ignoradas da Mente, Três Homens Perigosos, O Mistério do Hotel Bragança, tão grande era o nosso escrúpulo de dizer-lhe o nome, e afinal a inconfidente imprensa, Irá O Espanhol Ser Exilado, interrogação, Estamos Metidos Num Grande Sarilho, isto pensouo José Anaiço, não é título (2006:100).

Ou no excerto abaixo - quando a península para no oceano -, marcado por um forte tom de ironia e de saudosismo daqueles "tempos gloriosos", em que Portugal apresentavase como uma potência capaz de dividir, por meio do Tratado de Tordesilhas, os territórios do "Novo Mundo" com a Espanha, agora sua companheira de navegação:

Felizmente, a pressão da chamada opinião pública baixara, o vulgo deixara de fazer perguntas, bastava-lhe o estímulo das sugestões directas e indirectas suscitadas pelas formidáveis parangonas, Nasceu A Nova Atlântida, No Xadrez Mundial Moveu-se Uma Pedra, Um Traço de União Entre A América E A Europa, Entre A América E A Europa Um Pomo De Discórdia, Um Campo De Batalha Para O Futuro, mas o título que maior impressão causou produziu-o um jornal português, foi assim, Precisa-se Novo Tratado De Tordesilhas, é realmente a simplicidade do génio, o autor da ideia olhou para o mapa e verificou que, mais milha menos milha, a península estaria posta sobre o que fora a linha que, naqueles tempos gloriosos, dividira o mundo em duas partes, pataca a mim, pataca a ti, a mim pataca (2006:261).

A força que a mídia tem de influenciar as massas não é a única característica da sociedade capitalista retratada na obra. $\mathrm{O}$ narrador estabelece uma série de referências às tecnologias e aos avanços da ciência, aos vários meios de transporte e à cultura de massa quando cita filmes como "Os Pássaros", de Hitchcock, ou "Lassie". Em contrapartida, vê-se uma tendência arcaizante dos modos de vida da população, consequente das adversidades oriundas da separação da península. Em face disso, nos deparamos com uma atitude por vezes desesperada, quando muitas pessoas começam a invadir os hotéis. Os meios de locomoção - outrora dominados por carros e aviões - cedem lugar aos cavalos, carroças e até mesmo à ausência de qualquer transporte, como muitos fazem ao se tornarem andarilhos, como o personagem espanhol Roque Lozano - que cruza com as figuras centrais em alguns momentos da narrativa. Tal situação é descrita no trecho a seguir, quando o narrador afirma que "Por estas paragens é raro encontrar-se automóvel. Uma vez 
por outra passa um grande camião, leva abastecimentos às populações [...]. Anda muita gente a pé, outros vão de burro, se não fosse tão acidentado o terreno veríamos mais bicicletas" (2006:228).

Quando morre Dois Cavalos - o carro de Joaquim Sassa, que sempre aparece de forma personificada - e, assim como inúmeros outros automóveis deixados nas beiras das rodovias, tem de ser abandonado, os cinco personagens viajantes recorrem ao único recurso que possuem: uma galera, espécie de carroça, que estava na propriedade de Maria Guavaira e que passa a ter o mesmo nome do carro, por ser puxada por dois cavalos. É nesta galera que os cinco seguem com o fim de chegar aos Pirineus, ao local onde ocorreu a separação, longo percurso que fazem em condições precárias e dependendo da compra e revenda e roupas como meio de obter renda, vivendo de maneira semelhante a ciganos.

Outro ponto relevante, ao analisar A jangada de pedra, é o fato de Portugal e Espanha terem se desprendido da Europa juntos, e não apenas o primeiro, como seria de se esperar por ser essa uma obra da literatura lusitana. Isso indica uma proposta de junção entre os dois países, um incentivo para que eles unam forças ao invés de conflitarem - o que tem ocorrido ao longo dos séculos, de modo que elas acabaram configurando-se como nações inimigas. No romance, como passam a navegar pelo Atlântico juntas, tornam-se a única companhia uma da outra. No entanto, apesar de apresentar essa intenção, os caminhos da narrativa apontam para um rumo oposto, como verifica-se no trecho abaixo - cujo fecho é a conscientização do narrador de que a condição de ser ibérico significa muito mais do que uma mera configuração geográfica e territorial:

E sabe-se, ou julga-se saber, que entre certos meios políticos portugueses circula um movimento tendente a um entendimento bilaterial, embora de caráter não oficial, com a região da Galiza, o que, evidentemente, não irá agradar nada ao poder central espanhol, pouco disposto a tolerar irridências, por muito disfarçadas que se apresentem, havendo mesmo quem diga, com acerba ironia, e tenha posto a correr, que nada disto teria acontecido se Portugal fosse do lado dos Pirenéus, e, melhor ainda, se ficasse agarrado a eles ao dar-se a ruptura, seria a maneira de acabar, de uma vez para sempre, pela redução a um só país, com esta dificuldade de ser ibérico, mas aí enganam-se os espanhóis, que a dificuldade subsistiria, e não mais diremos (2006:248).

São muitos os trajetos percorridos pela Península Ibérica no oceano: desce, passa por Gibraltar, quase se choca com a ilha de Açores, sobe novamente, vai à esquerda, para, desce, gira. Por fim, ela se para novamente e se conserva em um local peculiar e repleto de 
significações: entre a América do Sul e a África. Não por acaso o romance tem fim quando a península se situa entre as suas principais ex-colônias. Tal localização sugere que o espaço mais apropriado para Portugal e Espanha não é mais a Europa, da qual, mesmo quando ainda se viam unidos territorialmente a ela pela cordilheira, não faziam parte. Esse "entre-lugar" no meio do Oceano Atlântico equipara a relação entre Portugal, América e África, em que aquele não se ostenta mais a posição de colonizador, em uma hierarquia que o eleva ao posto de dono destas como suas colônias; o que se propõe é uma relação de nações irmãs, frátrias, como uma "península que se desloca voluntariamente do envelhecido continente para ocupar o seu lugar cultural na bacia atlântica que agora revisita para reencontrar-se como irmã” (CERDEIRA, 2000:228). Assim, compõe-se, neste novo mapa, um conjunto ibero-afro-americano - ou, nas palavras de Saramago, uma "bacia cultural atlântica".

Como já foi dito, o romance A jangada de pedra foi publicado no momento de inserção de Portugal e Espanha na atual União Europeia. José Saramago chegou a declarar em entrevistas que via tal acontecimento como uma ameaça à identidade dos dois países, chamando a essa possível perda de "pesadelo do futuro". É na literatura, portanto, que esse caminho pelo qual seguia Portugal será recusado, buscando um novo rumo para a Península, rumo tal que Boaventura de Sousa Santos explica em "Onze teses por ocasião de mais uma descoberta de Portugal", da obra Pela mão de Alice:

Portugal é uma sociedade semiperiférica. Findo o ciclo do império, está a renegociar a sua posição no sistema mundial. Não é possível que num futuro próximo seja promovido ao centro do sistema ou despromovido para a sua periferia. É mais provável que a sua posição intermédia se consolide em novas bases (2008:63).

O romance finda, portanto, com a saída utópica encontrada por Saramago, cuja última frase “A vara de negrilho está verde, talvez floresça no ano que vem” (2006:291) indica possíveis mudanças e melhoras, em um tom esperançoso de renovação.

\section{Considerações finais}

O estudo ora apresentado buscou verificar de que modo a nação lusitana é representada na obra $A$ jangada de pedra, de José Saramago. Para tanto, antes se fez necessário compreender de que modo Portugal está inserido no contexto europeu e verificar os percursos que o levaram à atual configuração de nação semiperiférica, ou seja, de nação 
localizada geograficamente no centro, que já figurou no posto de maior potência europeia e exibe um passado glorioso que, no entanto, passou a ter a posição secundária e inferior que conhecemos hoje.

Além disso, por se tratar de um romance que muito se enreda no fantasioso, tornouse capital para a análise desse objeto de estudo atinar ao papel revelador que fantástico adquire na obra literária. Assim, foi possível visualizar como é estreita a relação entre literatura e História, quando, por meio da ficção e extrapolação da realidade, é possível adquirir um conhecimento muito mais legítimo da realidade social que nos inserimos do que aquilo que os dados e registros oficiais nos oferecem.

Partindo disso, verificou-se na análise do romance A jangada de pedra de que modo aparecem no plano literário - nesse caso, fundamentado no fantástico e no insólito -, as questões identitárias, históricas, políticas, linguísticas e literárias concernentes a Portugal, bem como as perspectivas oriundas da sua inserção, juntamente com a Espanha, na União Europeia.

Portanto, tendo como alicerce a relação paradoxal entre o passado de pioneirismo e conquistas e o presente decadente e enfraquecido da nação portuguesa - colocando-a em uma posição peculiar no âmbito mundial - A jangada de pedra foca-se no futuro, mostrando como a obra literária é capaz de indicar caminhos de maior ventura e sugerir um melhor destino frente à incômoda atual realidade de Portugal.

\section{Referências bibliográficas}

ABDALA JR, Benjamin. "Necessidade e Solidariedade nos Estudos de Literatura Comparada", In: De Vôos e Ilhas: Literatura e Comunitarismos. São Paulo: Ateliê Editorial, 2003.

ARANTES, Paulo. "Nação e reflexão". In: ABDALA JR, Benjamin e CARA, Salete de Almeida (orgs.). Moderno de nascença: figurações críticas do Brasil. São Paulo: Boitempo, 2006.

BRANCO, Célia. "Utopia e distopia em A jangada de pedra de José Saramago". 2008. Disponível em http://www.fcsh.unl.pt/docentes/cceia/documentos-cceia/docsceia/ensaiosmst/celia_branco_Jangada.docx/view 
CANDIDO, Antonio. Literatura e sociedade. $9^{\mathrm{a}}$ ed. Rio de Janeiro: Ouro sobre azul, 2006. CERDEIRA, Teresa Cristina. O avesso do bordado: ensaios de literatura. Lisboa: Caminho, 2000.

HOBSBAWM, Eric. "A nação como novidade: da revolução ao liberalismo", In: Nações e nacionalismo desde 1780. $5^{\mathrm{a}}$ ed. Rio de Janeiro: Paz e terra, 1990.

IANNI, Octavio. "Nação e narração", In: AGUIAR, Flavio (org.). Antonio Candido: pensamento e militância. São Paulo: Editora Fundação Perseu Abramo: Humanitas/FFLCH/USP, 1999.

LOURENÇO, Eduardo. "Identidade e memória" e "Portugal - identidade e imagem", In: Nós e a Europa: ou as duas razões. $4^{\mathrm{a}}$ ed. Lisboa: Imprensa Nacional/Casa da Moeda, 1994.

"Portugal como destino", In: Mitologia da saudade seguido de Portugal como destino. São Paulo: Companhia das Letras, 1999.

PAIVA, José Rodrigues de. "Revolução, renovação: caminhos do romance português no século XX”. In: MARTINS, Elizabeth Dias; PONTES, Roberto e BARROS, Patrícia Elainny Lima (orgs.). Falas \& Textos: Escritos de Literatura Portuguesa. Fortaleza: Universidade Federal do Ceará, 2010.

PERRONE-MOISÉS. Leyla. "Paradoxos do nacionalismo literário na América Latina”, In: Vira e mexe nacionalismo: paradoxos do nacionalismo literário. São Paulo: Companhia das Letras, 1990.

PESSOA, Fernando. Mensagem. Porto Alegre: L\&PM, 2007.

REIS, Carlos. História crítica da literatura portuguesa. Vol IX. Lisboa: Verbo, 2005.

RIBEIRO, Margarida Calafate. Uma História de Regressos: Império, Guerra Colonial e Pós-colonialismo. Porto: Afrontamento, 2004.

SANTOS, Boaventura de Sousa. Pela mão de Alice: o social e o político na pósmodernidade. $12^{\mathrm{a}}$ ed. São Paulo: Cortez, 2008.

SARAMAGO, José. A jangada de pedra. São Paulo: Companhia das Letras, 2006.

SECCO, Lincoln. A Revolução dos Cravos. São Paulo: Alameda, 2004. 